\title{
ZKUŠENOSTI S PILOTNÍ VÝUKOU AKADEMICKÉHO PSANÍ NA OPF SU
}

\author{
Krystyna Heinz, Emil Horký, Irena Orszulik
}

Klíčová slova:

akademické psaní, projekt, prezentace, metodika, evaluace, sebereflexe, pilotní kurz, dotazník

Key words:

academic writing, project, presentation, teaching mehtod, evaluation, self-reflection pilot course, questionnaire

\begin{abstract}
Abstrakt
Př́ispěvek se zabývá zavedením předmětu Tvorba a prezentace odborného textu do kurikula Obchodně podnikatelské fakulty v Karviné. Cílem př́spěvku je poukázat na nedostatky $\mathrm{v}$ oblasti akademického psaní na úrovni bakalářských prací a navrhnout změny, které povedou k jeho zlepšení. Na základě dotazů studentů v průběhu vedení seminářù jsou analyzovány obtíže, které studenty při psaní závěrečné práce doprovázejí. Přiložené vyhodnocení evaluačního dotazníku po ukončení pilotního kurzu předmětu Tvorba prezentace odborného textu dává podnět $\mathrm{k}$ jeho další inovaci.
\end{abstract}

\begin{abstract}
The article focuses on integration of a new subject Academic writing into the curriculum of School of Business Administration in Karviná. The aim of the paper is to analyse the present status of diploma project supervision, point at the main imperfections in academic writing on BA level, and to suggest improvements. Based on the inquiries, recorded during the seminars the difficulties affecting final projects writing are presented. The paper also presents our evaluation questionnaire research results carried out after the Academic Writing pilot course. The research, except the pilot course evaluation, has brought numerous stimuli for further improvement in the course content, instruction, and organisation. The stimuli are to be integrated in the new modified version of the Academic Writing course.
\end{abstract}

\section{Úvod}

K výcviku dovedností psaní odborných textů (Academic Writing) a také k jejich prezentaci nejsou studenti, s výjimkou filologických oborů, na českých vysokých školách dostatečně vedeni a motivování. Vyplývá to zřejmě z tradice české stylistiky, kdy umění psát je považováno zejména za rys osobnosti a talentu pisatele, nikoliv, jak je tomu v anglosaském světě, za dovednost, kterou je třeba rozvíjet, cvičit a zdokonalovat.

\section{Výuka akademického psaní na českých vysokých školách}

Výuka psaní odborných textů a jejich prezentace je na VŠ nefilologického zaměření téměř nulová. Studenti jsou sice $\mathrm{v}$ semináŕích motivováni $\mathrm{k}$ psaní referátů, seminárních prací, částečně $\mathrm{k}$ tvorbě rešerší, ale jejich vedení je nesystematické a $\mathrm{v}$ některých případech žádné. Myšlenka zavést do studijních programů bakalářské formy studia závazný předmět Tvorba a prezentace odborných textů vychází ze zkušeností s hodnocením bakalářských závěrečných prací, reflektuje rovněž poznatky dalších kolegů s vedením a hodnocením těchto prací a $\mathrm{v}$ neposlední řadě reaguje na podněty studentů, kteří se potýkají s problémy a kladou otázky 
typu: co je to odborný text, jak má vypadat abstrakt, jak mám pracovat s odkazy a citacemi, kdy je práce původní, do jaké míry musím citovat, apod.

K odbornému textu přstupujeme z hlediska jeho kognitivní a komunikativní povahy ve smyslu návaznosti na tradice rétoriky, která je vnímána především jako umění přednášet, mluvit, prezentovat, přesvědčovat, nicméně reflektuje rovněž psanou podobu jazyka. Odborný a vědecký styl chápeme $\mathrm{z}$ hlediska celkového účelu, tj. $\mathrm{z}$ hlediska funkce jazykového projevu. Zajímá nás míra závaznosti norem, které je třeba respektovat (Kraus, 2008, s. 88) s ohledem na požadavky jednotlivých redakcí, škol, institucí i diferencované pokyny vztahující se k ustálenosti jazyka v prŕslušné oblasti, jeho terminologická správnost, kompozice, pokyny k formálnímu uspořádání textu, uvádění bibliografických údajů apod.

Zabýváme se tvorbou titulků, kompozicí vědeckého textu včetně psaní abstraktu, prostředky koherence textu, smyslem a funkcí citací, aj. Je zdůrazněn rovněž procesuální charakter tvorby závěrečné práce jako projektu, vycházejícího z praktických dovedností a teoretických znalostí studentů

Při tvorbě nového předmětu jsme vycházeli ze zkušeností s výukou cizích jazyků (angličtina, němčina) a předmětů komunikačních (interkulturní komunikace, rétorika, komunikační dovednosti, vyjednávání), které nás utvrdily v poznání, že současný student ekonomické fakulty, ke kterým Obchodně podnikatelská fakulta v Karviné SU v Opavě patří, není vybaven dostatečnou kompetencí v psaní a prezentaci odborných textů. Problém souvisí v obecné rovině rovněž s rozvíjením komunikačních a kognitivních kompetencí studentů, jejich př́stupem ke kvalitním informacím, schopností kriticky myslet a formulovat své názory. Jako inspirace nám posloužily publikace předních českých lingvistů (Čmejrková, Daneš, Světlá, 1999) a dalších autorů (Liška, 2010, Geršlová, 2009, Šesták 2000, Eco 1997), kteří se věnují problematice odborného stylu, psaní diplomových, vědeckých a odborných prací. Souhlasíme s názorem (Daneš, 1999), že student má být v kompetenci psaní odborných textů dostatečně a kvalifikovaně trénován.

\section{Zaměření a metodika výuky předmětu Tvorba a prezentace odborného textu}

Předmět Tvorba a prezentace odborného textu jsme pojali jako kontinuální, promyšlený a ř́zený proces, který napomáhá rozvoji osobnosti a myšlení autora. Projektová povaha práce spočívala $\mathrm{v}$ postupném promýšlení dílčích kroků, které povedou $\mathrm{k}$ výslednému produktu (seminární práce, bakalářská práce). Naším cílem bylo rovněž zdůraznit autorský postoj při tvorbě písemné práce ve smyslu zodpovědnosti za použité zdroje, metody, techniky a postupy. Studenti pracovali v semináŕích metodou autonomního učení a sebereflexe.

První blok výukové části si kladl za cíl hledat odpovědi na otázky, kdy je odborná práce etická a kdy má rysy odborného stylu. V čem spočívá etika při psaní diplomové práce, jaké jsou základní charakteristiky vědeckého funkčního stylu. Pokusili jsme se nastínit studentům metody vědecké argumentace a základní metody vědeckého postupu. Pro názornost orientace $\mathrm{v}$ řešeném tématu jsme uplatnili analyticko-syntetickou metodu s důrazem na obtíže a rizika, která mohou řešení zvoleného tématu doprovázet.

V druhém výukovém bloku jsme se zaměřili na projektovou činnost. Studenti byli vedeni $\mathrm{k}$ vymezení tématu řešení a formulaci základních výzkumných otázek. Základní problémy, se kterými se studenti v př́ípravné fázi potýkali, byly komunikační a interakční povahy. Obtíže se vyskytovaly při formulaci odpovědí na otázku, proč jsem si dané téma zvolil, jak souvisí s mými teoretickými poznatky a praktickými zkušenostmi. Další oblastí bylo stanovení 
postupu práce, tzn. způsobu, jak dané téma řešit. Ukázalo se, že studenti nedostatečně znají možnosti využívání informačních zdrojů, které má fakulta k dispozici, neumí pracovat s elektronickými databázemi a zdroji, které jsou běžně dostupné v knihovnách. Velkou bariérou byla neprripravenost formulovat problém $\mathrm{k}$ řešení, klást otázky, které hodlám postupně řešit. Ve většině príípadů studenti zaměňovali cíl práce za metodu postupu při řešení úkolů.

Třetí blok výuky se týkal praktických kroků při tvorbě odborného textu. Studenti se zabývali kompoziční strukturou odborného textu podle modelu IMRAD (Introduction, Methods, Results, Discussion), rozvíjením tematických posloupností, obsahově-logickými vztahy a kompozici textu obecně, analyzovali př́klady odborných textů s cílem rozvíjet textační a kompoziční kompetenci. Důraz byl kladen na formulační přehlednost, srozumitelnost a jednoznačnost odborného stylu. Dále se zabývali vztahem tématu a názvu práce, strukturou a funkcí abstraktů, a také komunikačními a stylistickými postupy při tvorbě abstraktu v anglickém jazyce. Studenti byli seznámeni s psaním abstraktů a esejů v angličtině s ohledem na standardizaci stylu.

Poslední blok byl věnován prezentaci odborných textů. V teoretické rovině byl popsán komunikační model prezentací s důrazem na jasnost, srozumitelnost, přehlednost. a intencionální složku sdělení /zaujmout, informovat, přesvědčit/. Následně byly analyzovány verbální, neverbální a paralingvistické složky veřejných projevů s cílem demonstrovat a upozornit na chyby začínajících řečníků. Studenti se seznámili s jednotlivými fázemi př́pravy prezentace, počínaje identifikací cílové skupiny přes účel odborného projevu a jeho interakční, sociální a interkulturní funkci. Poslední část byla věnována obsahové a formální stránce prezentací na odborné téma.

\section{Akademické psaní v angličtině}

Psaní abstraktů a esejů v angličtině spadá do oblasti akademického jazyka a tvoří disciplínu, která se nazývá Academic Writing. Vzhledem k tomu, že úroveň výstupní znalosti všeobecné angličtiny na konci střední školy v poslední dekádě paradoxně klesá a studentům také chybí vhodná motivace ke studiu jazyka na vysoké škole, pro studenty je velmi obtižné používat akademickou angličtinu pro napsání abstraktu diplomové práce. Běžnými chybami jsou nesprávná volba odpovídající slovní zásoby, uspořádání odstavců a jejich návaznost, celková ucelenost psaného textu a používání gramatických jevů adekvátních pro tento styl.

Koncepce akademického psaní předpokládá standardizovaný styl, který je velmi př́sný a hutný. Používá pouze prosté gramatické časy, ve specifických situacích trpný rod, větnou kondenzaci, a zvláště jazykové prostředky přispívající $\mathrm{k}$ vytvoření koheze a koherence a vhodná volba formálnější slovní zásoby. Nerodilí mluvčí se tedy musejí řídit specifickými pravidly, která je tř̌eba při tvorbě textu $\mathrm{v}$ akademické angličtině dodržovat, a proto prŕprava na psaní musí být aktivní komunikace, která zahrnuje diskuse, interakci s vyučujícími, skupinovou práci a práci ve dvojicích. Díky získaným zkušenostem pak jsou studenti schopni samostatně kultivovat své kritické myšlení (Cohen, Miller, 2003).

Tvorba abstraktu $\mathrm{v}$ angličtině $\mathrm{v}$ rámci prezentovaného předmětu Tvorba a prezentace odborného textu zahrnovala následující kroky:

- název práce $\mathrm{v}$ angličtině

- definice abstraktu, 
- obsah abstraktu,

- postup psaní,

- struktura abstraktu,

- jazyk abstraktu,

- jazyková cvičení, zaměřená zvláště na spojovací slova, trpný rod a větnou kondenzaci,

- volba vhodné slovní zásoby,

- prŕklady abstraktů.

Čeští studenti čelí především obtížím týkajícím se použivání vhodných spojovacích slov a formální slovní zásoby. V syntaktické oblasti mají tendenci vyhýbat se tvarům trpného rodu a dávají přednost vedlejším větám před prostředky větné kondenzace. Důvody těchto problémů spočívají pravděpodobně kromě chabé znalosti angličtiny také v neznalosti mateřského jazyka, zvláště slovních druhů, větných členů a formálních vztahů.

\section{Vyhodnocení pilotního kurzu}

Po ukončení pilotního kurzu se studenti měli možnost vyjádřit $\mathrm{k}$ jeho průběhu, poukázat na nedostatky a navrhnout změny. Dotazníkového šetření se zúčastnilo 264 respondenti̊. Byly jim položeny čtyři uzavřené a jedna otevřená otázka s cílem získat zpětnou vazbu a navrhnou další inovace.

1. Domníváte se, že jste po absolvování předmětu schopni lépe uchopit a pojmout Vaši bakalářskou práci?

Tabulka č. 1

\begin{tabular}{|c|c|}
\hline & Počet \\
\hline \hline ano & 183 \\
\hline ne & 25 \\
\hline nevím & 56 \\
\hline \hline celkem & $\mathbf{2 6 4}$ \\
\hline
\end{tabular}


2. Uved'te prosím, v čem nejvíce Vám předmět pomohl:

(lze označit více možností)

Tabulka č. 2

\begin{tabular}{|l|c|}
\hline & počet \\
\hline \hline v uchopení a stanovení cíle BP (bakalářské práce) & 128 \\
\hline v definování hypotéz BP & 33 \\
\hline v tvorbě osnovy BP & 103 \\
\hline v provádění vlastního průzkumu & 15 \\
\hline v aplikaci metod pracování a vyhodnocování průzkumu & 28 \\
\hline ve formulaci závěrů BP & 50 \\
\hline v tvorbě struktury práce & 150 \\
\hline v napsaní abstraktu (anglického) & 160 \\
\hline v jiném & 46 \\
\hline
\end{tabular}

\section{v jiném:}

$15 \mathrm{x}$ citace

$12 x$ jak by měla vypadat prezentace BP( bakalářská práce)

$3 \mathrm{x}$ v celkové orientaci ohledně $\mathrm{BP}$, vyvarování se určitých slov

3x v neverbální komunikaci, verbální komunikaci

4x pomohl mi se rozhýbat a začít psát, nestresovat, motivace začít konečně něco dělat 1x vytvoření obrazu o samotné obhajobě BP

1x ve věcných radách při psaní abstraktu v anglickém jazyku

$1 \mathrm{x}$ vysvětleno jak postupovat, vysvětleny neznámé pojmy

1x možnost doptat se na nejasnosti

1x v odstranění stylistických chyb při psaní BP

1x v porozumění, co vlastně je odborný text

1x v psaném projevu (užívání/neužívání slov)

$1 \mathrm{x}$ na co si dát pozor

1x knihovna - zdroje - literatura 


\section{Jak jste byli spokojeni s kvalitou přednášek?}

Tabulka č. 3

\begin{tabular}{|l|c|}
\hline & počet \\
\hline \hline silně spokojen/a & 44 \\
\hline mírně spokojen/a & 184 \\
\hline nevím & 14 \\
\hline mírně nespokojen/a & 20 \\
\hline silně nespokojen/a & 2 \\
\hline \hline Celkem & 264 \\
\hline
\end{tabular}

4. Jste rádi, že se tento předmět začal vyučovat?

Tabulka č. 4

\begin{tabular}{|l|c|}
\hline & počet \\
\hline \hline ano & 209 \\
\hline ne & 55 \\
\hline \hline celkem & 264 \\
\hline
\end{tabular}

\section{Uved'te Vaše doporučení, co ještě zařadit do výuky v daném předmětu:}

- Výuka se mi zdála zrychlená tím, že to byla bloková výuka, tak nám chtěli vyučující sdělit co nejvíce informací.

- Předmět vyučovat v LS, aby se student mohl nanečisto připravit na obhajobu BP (bakalářská práce).

- 1. možnost - tutoriál online - ukázky dobrých a špatných metod atd., 2. možnost - 1x týdně nebo $1 \mathrm{x}$ za 2 týdny početně menší skupiny studentů.

- Kdyby byl předmět zařazen dříve, byl by pro nás více přínosný - 2. ročník studia.

- Předmět by měl být vyučován individuálně pro jednotlivé katedry.

- Tento předmět bych pojala jiným způsobem, a to místo dlouhých přednášek vyučovat v semináŕích, kde bude méně studentů.

- Kratší doba vyučování.

- Více praxe a názorných př́kladů, kratší vyučovací doba.

- Zkrácení doby trvání výuky, přednášky př́liš dlouhé, vyučovat v semináŕích.

- Nižší počet hodin, ukázky prací a možnost nahlédnutí do nich.

- Probírat vše více do hloubky.

- Rozpracování osnovy, individuální přístup k jednotlivým oborům.

- Zaměřit se také na úvod BP, jak ho pojmout.

- Tištěné praktické texty co dělat či nedělat.

- Názorné ukázky chyb v BP. Př́klad prezentace k obhajobě a vytyčení chyb.

- Ukázat starší bakalářské práce a ukázat na nich chyby, kterých se studenti dopustili.

- Především bych doporučoval, aby se vyučovalo to, co vedoucí BP opravdu vyžadují, protože zatím se to príliš neshoduje. 
- Rozebrat více jednotlivé kapitoly BP.

- Sdělit na co se máme v obhajobě hlavně zaměřit, čím nejlépe začít.

- Přinést nějakou starší BP, a na ní ukázat chyby a také pozitivní věci.

- Sjednotit výklady vedoucích BP s vyučujícími tohoto předmětu.

- Vysvětlit, jak se píšou citace $\mathrm{z}$ internetových zdrojů.

- Více o psaní citací.

- Více praktických ukázek, aktivita z řad studentů.

- Více konkrétních ukázek BP.

- Uvádět konkrétní př́klady, ukázky BP.

- Více praktických zkušeností.

- Konkrétní ukázky prací.

- Více ukázek (abstraktů - jak se vyvarovat chybám).

- Vyhodnocování vlastních průzkumů.

- Jak vyhodnocovat výsledky z průzkumu.

- Formátování práce (např. v MS Wordu).

- Metody vyhodnocování průzkumu - ne teoreticky, ale prakticky.

- Tvorbu dotazníků a jejich následné zpracování.

- Abstrakt $\mathrm{v}$ angličtině by se měl psát $\mathrm{v}$ dřívějších přednáškách a ne až v poslední, když už je dávno odevzdaný na katedře.

- Emailové kontaktování vyučujícího k opravení abstraktu v AJ.

- Myslím si, že náplň předmětu byla celkem dostatečná. V některých věcech došlo pouze $\mathrm{k}$ připomenutí.

- Podle mého názoru, je pro nás důležité znát náležitosti BP. Ty jsme se dozvěděli a vše, co se týká správného psaní a formulace. Nevidím nic, co by na výuce chybělo.

- Během výuky jsem se dozvěděla vše, co jsem ohledně své BP potřebovala vědět.

- Ve výuce bylo dostatek informací, které mi pomohly.

- Vše podstatné bylo řečeno.

\section{Zdroj: Vlastní zpracování}

Vyhodnocení dotazníku potvrdilo naše předpoklady, že největší obtíže budou mít studenti zejména v oblasti formulace abstraktu, psaní abstraktu v angličtině, tvorby struktury práce a osnovy, uchopení a stanovení cíle práce. Na tyto znalosti a dovednosti byl pilotní kurz zaměřen.

Dále z šetření vyplynulo, že více pozornosti bude vhodné při inovaci sylabu věnovat průzkumným metodám a technikám, aplikaci těchto metod a jejich vyhodnocování, formulaci hypotéz, výzkumných záměrů, aj. Bude nutno rozpracovat metodiku výuky předmětu s ohledem na autonomní učení a lépe využit prvků sebereflexe a sebeevaluace u studentů.

\section{Závěr}

Zkušenosti s vedením a vyhodnocením pilotního kurzu, a také výsledky evaluačního dotazníku potvrdily původní předpoklad, tj. nízkou úroveň znalostí problematiky akademického psaní a nutnost tuto dovednost cvičit. 
Předmět Tvorba a prezentace odborného textu se bude dále vyvíjet zejména po metodické a odborné stránce. Do budoucna bude hlouběji reflektovat aspekty metodologie vědecké práce, a také se více věnovat průzkumným metodám a technikám ve spolupráci s ostatními katedrami na OPF SU.

\section{Literatura:}

[1] ANDREWS, S.2009. Teaching Academic Writing - a Blended Approach, In: Modern English Teacher, OUP, Vol.18, Number 3 , July, p. 63-65.

[2] COHEN, R.F., MILLER, J.L.2003. Reason to Write, OUP, p.iv, ISBN 0-19-436773-8.

[3] ČMEJRKOVÁ,S., DANEŠ, F., SVĚTLÁ,J. 1999. Jak napsat odborný text. Praha: Leda. ISBN 80-85927-69-1.

[4] ECO, U. 1997. Jak napsat diplomovou práci. Olomouc: Votobia. ISBN 80-7198-173-7.

[5] GERŠLOVÁ,J.2009 Vádemékum védecké a odborné práce. Praha: Professional Publishing.ISBN 978-80-7431-002-7.

[6] KRAUS, J.2008. Jazyk v proměnách komunikačních médii. Praha: Karolinum. ISBN 97880-246-1578-3.

[7] ŠESTÁK,Z. 2000.Jak psát a přednášet o vědě. Praha: Academia 2000. ISBN 80-2000755-5.

JEL I21, Z19

\section{PhDr. Krystyna Heinz}

Katedra společenských věd

Obchodně podnikatelská fakulta Karviná

Slezská Univerzita v Opavě

Univerzitní náměstí 1934/3, 73340 Karviná

Tel.: 596398459

heinzova@opf.slu.cz

\section{Mgr. Emil Horký}

Katedra společenských věd

Obchodně podnikatelská fakulta Karviná

Slezská Univerzita v Opavě

Univerzitní náměstí 1934/3, 73340 Karviná

Tel.: 596398459

horky@opf.slu.cz

Mgr. Irena Orszulik, Ph.D.

Katedra společenských věd

Obchodně podnikatelská fakulta Karviná

Slezská Univerzita v Opavě

Univerzitní náměstí 1934/3, 73340 Karviná

Tel.: 596398459

orszulikova@opf.slu.cz 